\title{
BUFORY KAPITAŁOWE JAKO DETERMINANTY BEZPIECZEŃSTWA SEKTORA BANKOWEGO: ANALIZA EMPIRYCZNA SPEKNIENIA WYMOGU POŁĄCZONEGO BUFORA
}

\section{Ivanna Chaikovska*}

\section{CAPITAL BUFFERS AS DETERMINANTS OF BANKING SECTOR SECURITY: EMPIRICAL ANALYSIS OF MEETING THE COMBINED BUFFER REQUIREMENT}

\begin{abstract}
The purpose of the article. The purpose of the article is to assess the importance of capital buffers in ensuring the security of individual banks and the entire banking sector. This scientific study characterizes the amount of the buffer requirement, countercyclical buffer, systemic risk buffer, and buffer of other institutions of systemic importance in the Polish banking sector. In addition, an empirical analysis of the capital requirement was carried out, taking into account the combined buffer requirement and the total capital ratio in the Polish banking sector.

Methodology. The calculations used financial data provided by the Polish Financial Supervision Authority and consolidated financial statements of Polish banks. To achieve the set goal, a methods of comparing documents and legal acts were used (especially in the part concerning the characteristics of capital buffers) and methods of descriptive statistics (in the empirical part of the subsection).
\end{abstract}

Results of the research. The above analysis is the basis for answering the question whether postcrisis capital buffers increase the level of security of the Polish banking sector.

Keywords: bank, banking sector, own funds, capital buffers, security.

JEL Class: G21, G3, E5, F5.

\footnotetext{
* Mgr, doktorantka, Wydział Zarządzania i Komunikacji Społecznej, Uniwersytet Jagielloński; https://orcid.org/0000-00029425-2852.
} 


\section{WSTĘP}

Fundusze własne banku nie są w stanie zaabsorbować skutków ekstremalnych zdarzeń rynkowych, które prowadzą do pojawienia się strat zagrażających wypłacalności banku, tzw. strat katastroficznych. Są to straty, które występują jedynie w warunkach skrajnych, tj. takie, których zaistnienie jest bardzo mało prawdopodobne, ale możliwe (np. ryzyko systemowe, ryzyko związane z zagrożeniem epidemiologicznym COVID-19). Doświadczenia globalnego kryzysu finansowego w latach 2007-2009 pokazują, iż straty katastroficzne mogą pojawić się wskutek niedoszacowania ryzyka systemowego i doprowadzić do niewypłacalności banków, a tym samym do ich bankructw oraz zachwiania poziomu bezpieczeństwa poszczególnych banków, jak i całego sektora bankowego.

Powyższe uświadomiło potrzebę wprowadzenia narzędzi mających na celu absorbowanie strat katastroficznych. Dlatego w okresie pokryzysowym po raz pierwszy został wprowadzony obowiązek tworzenia buforów kapitałowych, które byłyby uzupełnieniem miar adekwatności kapitałowej, płynnościowej oraz wskaźników jakości aktywów w celu zapewnienia bezpieczeństwa poszczególnych banków oraz całego sektora bankowego.

Celem artykułu jest ocena znaczenia buforów kapitałowych w zapewnieniu bezpieczeństwa poszczególnych banków oraz całego sektora bankowego. W niniejszym opracowaniu scharakteryzowano wysokość wymogu bufora zabezpieczającego, bufora antycyklicznego, bufora ryzyka systemowego, bufora innych instytucji o znaczeniu systemowym w polskim sektorze bankowym.

W empirycznej części artykułu została przeprowadzona analiza wymogu kapitałowego uwzględniającego wymóg połączonego bufora oraz łącznego współczynnika kapitałowego w polskim sektorze bankowym. W obliczeniach wykorzystano dane finansowe udostępnione przez Komisję Nadzoru Finansowego oraz skonsolidowane sprawozdania finansowe banków w Polsce. Powyższa analiza jest podstawą do odpowiedzi na pytanie, czy pokryzysowe bufory kapitałowe zwiększają poziom bezpieczeństwa polskiego sektora bankowego.

Aby osiągnąć postawiony cel posłużono się metodą porównywania dokumentów i aktów prawnych (szczególnie w części dotyczącej charakterystyki buforów kapitałowych) oraz metodami statystyki opisowej (w empirycznej części podrozdziału).

\section{CHARAKTERYSTYKA BUFORÓW KAPITAŁOWYCH: RODZAJE, CELE, WYSOKOŚĆ ORAZ HARMONOGRAM WDRAŻANIA}

Głównym narzędziem zarządzania ryzykiem bankowym przed nieoczekiwanymi stratami jest kapitał banku. Z perspektywy regulacji prawnych i organów nadzoru, jak również bezpieczeństwa ważnym jest kapitał regulacyjny (regulatory capital). 
Kapitał regulacyjny jest określany przez ostrożnościowe normy prawne precyzujące wymogi kapitałowe, które mają pokryć ryzyko prowadzonej działalności bankowej. W szczególności, definicja kapitału regulacyjnego została wprowadzona w ramach pokryzysowych wytycznych bazylejskich, tzw. Bazylea III. Kapitał regulacyjny jest utożsamiany z funduszami własnymi banku, i jest zdefiniowany jako suma (Rozporządzenie CRR, art. 26-28):

1) kapitału Tier 1 (Going-Concern Capital) - kapitału służącego do pokrywania strat w warunkach utrzymywania przez bank wypłacalności. Wyróżniono w nim:

- kapitał podstawowy Tier 1 (Common Equity Tier 1 - CET1), powstały w wyniku emisji akcji zwykłych, zatrzymania zysków oraz tworzenia rezerw,

- kapitał dodatkowy Tier 1 (Additional Tier 1 - AT 1), którego źródłem są emitowane przez banki instrumenty dłużne, opłacone i nieposiadające określonej daty zwrotu; za zgodą krajowej instytucji nadzoru mogą podlegać wykupowi, lecz po upływie co najmniej pięcioletniego okresu;

2) kapitału Tier 2 (Gone-Concern Capital) - kapitału nabierającego znaczenia w wypadku utraty wypłacalności lub likwidacji banku. Tworzą go odpisy na rezerwy oraz pozostała część długu podporządkowanego, której nie zaliczono do dodatkowego Tier 1.

Kapitał Tier 1 (tj. kapitał akcyjny w pełni opłacony, rezerwy jawne oraz przeniesione straty i zyski) służy do pokrywania strat w warunkach wypłacalności banku, i pozwala bankowi kontynuować normalną działalność (Capital requirements for the banking sector...). Jakościowo najlepszy kapitał Tier 1 jest tzw. „,kapitał podstawowy Tier 1" (CET1). Z kolei, kapitał Tier 2 - służy do pokrywania strat w warunkach utraty wypłacalności banku. Pozwala bankowi spłacić deponentów i uprzywilejowanych wierzycieli, gdy bank przestał być wypłacalny. Istotnym jest faktem, iż fundusze uzupełniające nie mogą przekraczać 100\% wartości funduszy podstawowych. To wskazuje, iż kapitał regulacyjny banku jest jednym z głównych determinant jego bezpieczeństwa.

Wyżej przedstawiona struktura kapitału regulacyjnego jest podstawą oceny adekwatności kapitałowej banku, m. in. za pomocą współczynników adekwatności kapitałowej.

W okresie pokryzysowym w ramach regulacji Bazylea III oraz pakietu CRD IV/CRR, zostały wprowadzone narzędzia mające na celu absorbowanie strat katastroficznych poprzez tworzenia buforów kapitałowych (Miklaszewska i Kil, 2019: 174).

Na pokrycie strat o tym charakterze zostały powołane m.in.:

- bufor zabezpieczający (capital conservation buffer);

- bufor antycykliczny (countercyclical capital buffer);

- bufor ryzyka systemowego w instytucjach o znaczeniu systemowym (systemic risk buffer); 
- bufor globalnych instytucji o znaczeniu systemowym (global systemically important institutions - G-SIIs buffer);

- bufor innych instytucji o znaczeniu systemowym (other systemically important institutions - O-SIIs buffer).

Bufory kapitałowe, w szczególności zabezpieczający i antycykliczny, należy zaliczyć do narzędzi polityki makroostrożnościowej, które umożliwiają przeciwdziałanie ryzyku systemowemu. Ponadto bufory również mają na celu usunięcie mechanizmów procyklicznych w działalności bankowej. To oznacza, iż ich tworzenie powinno zapewniać gromadzenie przez banki, w okresach wzrostu gospodarczego wystarczający zapas kapitałów, który umożliwiłby absorpcję strat w okresach skrajnych warunków rynkowych (Marcinkowska, 2012: 66). Przy tym należy zaznaczyć, iż oprócz obowiązkowych 4,5\% kapitału podstawowego Tier 1 (wymóg określony rozporządzeniem CRR) wszystkie banki muszą utrzymywać odpowiedni poziom buforów kapitałowych. dysponować buforem zabezpieczającym i buforem antycyklicznym. Z jednej strony, nadwyżka kapitału podstawowego Tier 1 (CET1) $\mathrm{w}$ formie buforów kapitałowych powoduje obniżenie stopy zwrotu $\mathrm{z}$ kapitału, ale $\mathrm{z}$ drugiej strony - również prowadzi do obniżenia ryzyka bankructwa ${ }^{1}$.

Bufor zabezpieczający (capital conservation buffer) musi być utrzymywany z kapitału podstawowego Tier 1 (CET1) na poziomie 2,5\% łącznej kwoty ekspozycji na ryzyko ${ }^{2}$. Obowiązek tworzenia bufora zabezpieczającego w Unii Europejskiej wynika z art. 129 Dyrektywy Parlamentu Europejskiego i Rady 2013/36/UE z dnia 26 czerwca 2013 roku (Dyrektywa CRD IV: Art 128-129). Istotnym jest zaznaczyć, iż organy nadzorcze państw członkowskich mogą zwolnić z wymogu posiadania bufora zabezpieczającego małe i średnie banki, o ile nie zagraża to stabilności krajowego systemu finansowego.

W Polsce implementacja pokryzysowych regulacji w zakresie buforów kapitałowych została odzwierciedlona $\mathrm{w}$ ustawie o nadzorze makroostrożnościowym ${ }^{3}$. Zgodnie z art. 19 ust. 1 ustawy o nadzorze makroostrożnościowym, polskie banki są zobowiązane do utrzymywania bufora zabezpieczającego, czyli kwoty kapitału podstawowego Tier 1 (CET 1) w wysokości 2,5\% łącznej kwoty ekspozycji na ryzyko. W Polsce bufor zabezpieczający wprowadzany był stopniowo, szczegółowy harmonogram wdrażania wymogu bufora zabezpieczającego został przedstawiony w tabeli 1. Od 1 stycznia 2016 r. do 31 grudnia 2016 r. wysokość bufora

\footnotetext{
${ }^{1}$ „Nadwyżka” kapitałowa rozumiana jest jako ponadstandardowa ochrona przed ryzykiem niewypłacalności, podwyższająca reputację całej grupy (Pawłowicz, 2011: 18).

${ }^{2}$ Łączna kwota ekspozycji na ryzyko jest obliczona zgodnie z art. 92 ust. 3 CRR rozporządzenia na zasadzie indywidualnej i skonsolidowanej, zgodnie z częścią pierwszą tytuł II tego rozporządzenia.

${ }^{3}$ Należy podkreślić, że dotyczą one kapitału podstawowego Tier 1 (CET1) i są wymaganiami dodatkowymi w stosunku do wymogów stawianych funduszom własnym, o których mowa w art. 92 rozporządzenia CRR (Moser, 2018: 115).
} 
zabezpieczającego wynosiła 0,625\%, od 1 stycznia 2017 r. do 31 grudnia 2017 r. wzrosła do 1,25\%, od 1 stycznia 2018 r. wzrosła do 1,875\%, natomiast wartość docelowa 2,5\% zaczęła obowiązywać od 1 stycznia 2019 r.

Tabela 1. Harmonogram wdrażania wymogu bufora zabezpieczającego w Polsce

\begin{tabular}{|c|c|c|c|c|}
\hline Wyszczególnienie & 2019 & 2018 & 2017 & 2016 \\
\hline $\begin{array}{c}\text { Minimalna wartość bufora } \\
\text { zabezpieczającego }\end{array}$ & $2,5 \%$ & $1,875 \%$ & $1,25 \%$ & $0,625 \%$ \\
\hline
\end{tabular}

Źródło: opracowanie własne na podstawie art. 82, 83 oraz 84 Ustawy z dnia 5 sierpnia 2015 r...

Należy podkreślić, iż bufor zabezpieczający jest w zasadzie kapitałem zgromadzonym w okresie wzrostu gospodarczego, stanowiącym zabezpieczenie przed szokami w okresie dekoniunktury. Bufor ten jest wypracowaną nadwyżką powyżej poziomu minimalnego kapitału podstawowego Tier 1 (CET1), co w konsekwencji oznaczać będzie podniesienie współczynnika wypłacalności. Należy podkreślić, iż w sytuacji gdy bank nie spełnia w pełni wymogu bufora zabezpieczającego, stosowane są ograniczenia w zakresie wypłat zysków (Dyrektywa CRD IV: Art. 141 ust 2 i 3).

Kolejnym wymogiem bazującym na kapitale podstawowym Tier 1 (CET1) jest wymóg tworzenia bufora antycyklicznego (countercyclical capital buffer). Jest to instrument makroostrożnościowy dzięki któremu jest możliwe złagodzenie cyklicznych wahań poziomu kredytu w gospodarce i ich konsekwencji dla gospodarki. Ten bufor musi być utrzymany na poziomie łącznej kwoty ekspozycji na ryzyko pomnożonej przez średnią ważoną wskaźnika bufora antycyklicznego dla poszczególnych jurysdykcji, w których znajdują się poszczególne ekspozycje banku (Dyrektywa CRD IV: Art. 130, 140). Wskaźnik bufora antycyklicznego jest ustalany przez organy nadzoru krajowego i musi mieścić się w przedziale $0-2,5 \%$.

Należy podkreślić, iż wymóg bufora antycyklicznego oddziałuje dwutorowo i spełnia podwójną funkcję stabilizacyjną. Z jednej strony, poprzez akumulację kapitału zostaje wzmocniona odporność banków na ewentualne szoki. Z drugiej strony, zwiększenie wymogów kapitałowych przekłada się na wzrost kosztów kredytu, co z kolei powinno prowadzić do ograniczenia nadmiernego wzrostu kredytu w gospodarce, w szczególności możliwości wystąpienia boomów kredytowych. Tym samym spada prawdopodobieństwo wystąpienia zjawisk kryzysowych. Z kolei, odwrotny mechanizm działa w przypadku zwolnienia banku z wymogu bufora antycyklicznego, m.in. uwolniony kapitał pozwala bankom na zaabsorbowanie ewentualnych strat kredytowych oraz zapewnienie utrzymanie akcji kredytowej (Dobrzańska i Kurowski, 2019: 10). 
W Polsce, zgodnie z art. 23 ustawy o nadzorze makroostrożnościowym, Komitet Stabilności Finansowej co kwartał oblicza wartość odniesienia, którą jest zmienna odzwierciedlająca cykl kredytowy i ryzyko nadmiernego wzrostu akcji kredytowej. Minister Finansów ocenia wartość odniesienia co kwartał, a także określa w drodze rozporządzenia wskaźnik bufora antycyklicznego oraz dzień, od którego banki stosują ten wskaźnik (Moser, 2018: 115).

Obowiązek stosowania antycyklicznego bufora kapitałowego stał się powszechny w UE od 1 stycznia 2016 r. Podobnie jak w większości krajów UE, wskaźnika bufora antycyklicznego w Polsce od 2016 roku znajduje się na poziomie $0 \%$. Nie oznacza to, że ten instrument makroekonomiczny nie jest stosowany, a jedynie, iż ocena ryzyka systemowego nie wskazuje na konieczność zaostrzenia polityki makroostrożnościowej poprzez ustalenie wyższego wskaźnika bufora antycyklicznego (Dobrzańska i Kurowski, 2019: 10).

W celu zapobiegania i ograniczania długoterminowych niecyklicznych ryzyk systemowych lub makroekonomicznych wymaga się również utworzenia bufora ryzyka systemowego (systemic risk buffer), który oznacza kapitał podstawowy Tier 1 (CET 1) (Dyrektywa CRD IV: Art. 133). Bufor ustalany jest na poziomie 1-5\% kwoty ekspozycji znajdujących się w danym kraju, i może być wprowadzony w odniesieniu do całego systemu finansowego lub poszczególnego sektora (np. bankowego). Istotnym jest zaznaczyć, iż niespełnienie wymogu utrzymywania buforu ryzyka systemowego powoduje, że bank podlega ograniczeniom w zakresie wypłat zysków, jak również, iż bank może stać się przedmiotem działań dyscyplinujących (enforcement actions) ze strony organów nadzoru, np. sankcji. Zgodnie z rozporządzeniem Ministra Rozwoju i Finansów z 1 września 2017 r. w sprawie ryzyka systemowego, bufor ryzyka systemowego w wysokości 3\% łącznej kwoty ekspozycji na ryzyko obowiązuje w Polsce od 1 stycznia 2018 roku ${ }^{4}$.

Ponadto na instytucje o znaczeniu systemowym nałożone są obowiązki w tworzeniu dodatkowych buforów kapitałowych, $\mathrm{m}$. in.:

- bufora głobalnych instytucji o znaczeniu systemowym (global systemically important institutions - G-SIIs buffer).

- bufora innych instytucji o znaczeniu systemowym (other systemically important institutions - O-SIIs buffer).

Zaliczanie banków do kategorii globalnych instytucji istotnych systemowo wymaga przeprowadzenia analizy pod względem wielkości grupy, jej wzajemnych powiązań z systemem finansowym, zastępowalności usług i infrastruktury, złożoności grupy oraz jej działalności transgranicznej (Dyrektywa CRD IV: Art. 131). Na tej podstawie globalne instytucje o znaczeniu systemowym są dzielone na co najmniej pięć podkategorii. W zależności od tego $\mathrm{W}$ jakiej podkategorii znajduje się

${ }^{4} \mathrm{~W}$ dniu 16 marca 2020 roku Minister finansów po uwzględnieniu opinii KNF podpisał rozporządzenie dot. rozwiązania bufora ryzyka systemowego (3\%). Rozporządzenie Ministra Rozwoju i Finansów z 1 września 2017 r. w sprawie ryzyka systemowego, Dz.U. 2017, poz. 1776. 
systemowo ważny bank jest on zobowiązany do utrzymania bufora globalnych instytucji o znaczeniu systemowym na poziomie od 1-3,5\%. Bufor ten składa się z kapitału podstawowego Tier 1 (CET 1) (w relacji do łącznej kwoty ekspozycji na ryzyko) i ma względem niego charakter uzupełniający.

$\mathrm{Z}$ kolei, zaliczanie banku do kategorii innych instytucji istotnych systemowo wymaga przeprowadzenia analizy pod względem ich wielkości, znaczenia dla gospodarki Unii lub poszczególnego państwa członkowskiego, znaczenia działalności transgranicznej oraz wzajemnych powiązań (Dyrektywa CRD IV: Art. 131). Ta grupa banków jest zobowiązana do posiadania bufora innych instytucji o znaczeniu systemowym, który może wynieść do $2 \%$ i musi być poddany przeglądowi najmniej raz na rok.

W Polsce, przegląd adekwatności wskaźnika bufora innej instytucji o znaczeniu systemowym dokonuje KNF. Raz do roku KNF przeprowadza weryfikację banków zaliczonych do innych instytucji o znaczeniu systemowym (O-SII) na podstawie wielkości podmiotów, ich znaczenia dla gospodarki Rzeczypospolitej Polskiej i Unii Europejskiej, znaczenia działalności transgranicznej oraz ich wzajemnych powiązań z systemem finansowym. Decyzją z dnia 4 października 2016 r. KNF po raz pierwszy zidentyfikowała dwanaście banków jako inne instytucje o znaczeniu systemowym i nałożyła na nie obowiązek utrzymania buforów w wysokościach zaprezentowanych w tabeli 2. Należy przy tym zaznaczyć, iż dwa banki spółdzielcze, tj. Bank Polskiej Spółdzielczości oraz SGB-Bank, zostały zaliczone do innych instytucji o znaczeniu systemowym, dla których przewidziany poziom bufora został ustalony na poziomie 0\% (Komunikat KNF z dnia 14 listopada 2016 r.).

W wyniku następnego przeglądu adekwatności wskaźnika tego bufora, decyzją z dnia 19 grudnia 2017 r. KNF m.in. (Komunikat KNF z dnia 9 stycznia 2018 r.):

- dodatkowo zidentyfikowała Deutsche Bank Polska jako inną instytucję o znaczeniu systemowym;

- potwierdziła identyfikację jedenastu banków jako innych instytucji o znaczeniu systemowym i nałożyła na te banki bufory o wielkościach zaprezentowanych w tabeli 2 ;

- uchyliła decyzję z 4 października 2016 r. identyfikującą Raiffeisen Bank Polska jako inną instytucję o znaczeniu systemowym i nakładające na ten bank bufory kapitałowe.

Z kolei, w wyniku następnego przeglądu na podstawie danych z 31 grudnia 2017 r., KNF uchyliła decyzję identyfikującą Getin Noble Bank oraz Bank Millennium jako inne instytucje o znaczeniu systemowym, tym samym zniosła wymagania dotyczące utrzymania buforów innych instytucji o znaczeniu systemowym. Jak również, w ramach tego przeglądu KNF zidentyfikowała Alior Bank jako inną instytucję o znaczeniu systemowym i nałożyła obowiązek utrzymania bufora w wysokości 0,25\% kapitału podstawowego Tier I (Komunikat KNF z dnia 8 sierpnia 2018 r.). 
Wyniki przeglądu z dnia 15 października 2019 roku (na podstawie decyzji z dnia 14 października 2019 r.), wskazują iż w Polsce dziewięć banków jest zaliczanych do grupy innych instytucji o znaczeniu systemowym, są to banki uwzględnione w tabeli 2 (Komunikat KNF z dnia 15 października 2019 r.). W porównaniu do 2018 roku Deutsche Bank Polska oraz Alior Bank nie wypełniły kryteriów uznania ich za O-SII. Z kolei, dla niektórych banków poziom wskaźnika bufora innej instytucji o znaczeniu systemowym został podwyższony, m.in. dla Santander Banku (do 0,75\%), ING Banku (do 0,75\%) oraz mBanku (do 0,75\%) (tabela 2).

Tabela 2. Rozkład nałożonych lub utrzymanych buforów O-SII na podstawie przeglądu KNF w latach 2016-2020

\begin{tabular}{|l|c|c|c|c|c|}
\hline \multicolumn{1}{|c|}{ Nazwa banku } & $\begin{array}{c}\text { Decyzja } \\
\text { KNF z dnia } \\
9 \text { listopada } \\
2020 \text { r. }\end{array}$ & $\begin{array}{c}\text { Decyzja } \\
\text { KNF z dnia } \\
14 \text { paździer- } \\
\text { nika 2019 r. }\end{array}$ & $\begin{array}{c}\text { Decyzja } \\
\text { KNF z dnia } \\
31 \text { lipca } \\
2018 \text { r. }\end{array}$ & $\begin{array}{c}\text { Decyzja } \\
\text { KNF z dnia } \\
19 \text { grudnia } \\
2017 \text { r. }\end{array}$ & $\begin{array}{c}\text { Decyzja KNF } \\
\text { z dnia 4 paź- } \\
\text { dziernika } \\
2016 \text { r. }\end{array}$ \\
\hline PKO Bank & $1,00 \%$ & $1,00 \%$ & $1,00 \%$ & $0,75 \%$ & $0,75 \%$ \\
\hline Santander Bank & $0,75 \%$ & $0,75 \%$ & $0,50 \%$ & $0,50 \%$ & $0,50 \%$ \\
\hline Pekao Bank & $0,75 \%$ & $0,75 \%$ & $0,75 \%$ & $0,50 \%$ & $0,75 \%$ \\
\hline ING Bank & $0,50 \%$ & $0,50 \%$ & $0,50 \%$ & $0,50 \%$ & $0,50 \%$ \\
\hline mBank & $0,50 \%$ & $0,75 \%$ & $0,50 \%$ & $0,75 \%$ & $0,50 \%$ \\
\hline BNP Paribas Bank & $0,25 \%$ & $0,25 \%$ & $0,25 \%$ & $0,25 \%$ & $0,25 \%$ \\
\hline $\begin{array}{l}\text { Bank Handlowy } \\
\text { w Warszawie }\end{array}$ & $0,25 \%$ & $0,25 \%$ & $0,25 \%$ & $0,25 \%$ & $0,25 \%$ \\
\hline $\begin{array}{l}\text { Bank Polskiej } \\
\text { Spółdzielczości** }\end{array}$ & $0,10 \%$ & $0,10 \%$ & $0,00 \%$ & $0,00 \%$ & $0,00 \%$ \\
\hline SGB-Bank* & $0,10 \%$ & $0,10 \%$ & $0,00 \%$ & $0,00 \%$ & $0,00 \%$ \\
\hline Raiffeisen Bank Polska & - & - & - & - & $0,25 \%$ \\
\hline Bank Millennium & $0,25 \%$ & - & - & $0,25 \%$ & $0,25 \%$ \\
\hline Getin Noble Bank & - & - & - & $0,25 \%$ & $0,25 \%$ \\
\hline Deutsche Bank Polska & - & - & $0,25 \%$ & $0,25 \%$ & - \\
\hline Alior Bank & - & - & $0,25 \%$ & - & - \\
\hline
\end{tabular}

* Wcześniej Bank Zachodni WBK.

** Banki spółdzielcze zaliczane do innych instytucji o znaczeniu systemowym.

Źródło: opracowanie własne na podstawie Komunikatu KNF z dnia 14 listopada 2016 r.; Komunikatu KNF z dnia 9 stycznia 2018 r.; Komunikatu KNF z dnia 8 sierpnia 2018 r.; Komunikatu KNF z dnia 15 października 2019 r.; Komunikatu KNF z dnia 9 listopada 2020 r.

Wyniki ostatniego przeglądu, dokonane przez KNF, które zostały opublikowane 9 listopada 2020 roku (na podstawie decyzji z dnia 29 października 2020 r.), wskazują iż w Polsce dziesięć banków jest zaliczanych do grupy innych instytucji o znaczeniu systemowym (tabela 2). W 2020 roku jeden dodatkowy bank został zidentyfikowany jako O-SII, a mianowicie Bank Millennium, którego poziom 
wskaźnika bufora O-SII wynosił 0,25\%. W porównaniu do 2019 roku, w przypadku tylko jednego banku, a mianowicie mBanku, w 2020 roku została zmniejszona wysokość wskaźnika bufora OSII (z poziomu $0,75 \%$ do poziomu $0,50 \%$ ). Z kolei, według decyzji KNF, pozostałe banki zostały zobowiązane do utrzymywania bufora O-SII w wysokości zgodnej z decyzjami KNF wydanymi w latach poprzednich (Komunikat KNF z dnia 9 listopada 2020 r.).

\section{WYMÓG POŁĄCZONEGO BUFORA KAPITAŁOWEGO W POLSKIM SEKTORZE BANKOWYM W LATACH 2016-2019}

Wyżej wymienione wymogi buforów kapitałowych składają się na wymóg połączonego bufora, który jest wiążący dla banków w UE. W Polsce zgodnie z art. 55 ust. 4 ustawy o nadzorze makroostrożnościowym nad systemem finansowym i zarządzaniu kryzysowym w systemie finansowym wymóg połączonego buforastanowi sumę obowiązujących buforów w 2019 roku, tj.:

- bufora zabezpieczającego w wysokości 2,5\%;

- bufora antycyklicznego w wysokości 0\%;

- bufora ryzyka systemowego w wysokości 3\%;

- bufora innych instytucji o znaczeniu systemowym O-SII - określanego w drodze indywidualnej decyzji KNF.

Z powyższego wynika, iż w polskim sektorze bankowym w 2019 roku wymóg połączonego bufora bez uwzględnienia bufora innych instytucji o znaczeniu systemowym O-SII ukształtował się na poziomie 5,5\% kapitału podstawowego Tier 1 (CET 1). Uwzględniając wymóg utrzymania współczynnika kapitału podstawowego Tier 1 (CET1) na poziomie 4,5\%, poziom wymaganego kapitału podstawowego Tier 1 banków w Polsce w 2019 roku powinien wynosić 10\%. Z kolei, instytucje zaliczone do innych o znaczeniu systemowym były dodatkowo zobowiązane do utrzymania bufora innych instytucji o znaczeniu systemowym O-SII o wysokości określonej w drodze indywidualnej decyzji KNF (tabela 2). Uwzględniając najwyższy poziom bufora innych instytucji o znaczeniu systemowym O-SII (tj. 1\% w latach 2018-2019, oraz 0,75\% w latach 2016-2017), na wykresie 1 zostało przedstawione kształtowanie się wymogu połączonego bufora w latach 2016-2019 w polskim sektorze bankowym.

Z informacji zamieszczonych na wykresie 1 wynika, iż w latach 2016-2019 w polskim sektorze bankowym wymóg połączonego bufora miał tendencję wzrostową, z poziomu 1,375\% do poziomu 6,5\%. W 2019 roku, w porównaniu do 2016 roku, wymóg połączonego bufora wzrósł ponad trzykrotnie. Należy zaznaczyć, iż na wykresie 1 zostały również uwzględnione maksymalne wielkości docelowe buforów kapitałowych obowiązujące w Unii Europejskiej. Porównująć poziom wymogu połaczonego bufora w Polsce oraz w UE (tj. maksymalnie możliwy do 
implementacji), istotnym jest zaznaczyć, iż w 2019 roku w Polsce ten wymóg był ponad dwa razy niższy niż maksymalnie dostępny w Unii Europejskiej. To świadczy o tym, iż banki w Polsce zostały zwolnione z obowiązku utrzymania niektórych buforów, m.in., bufora antycyklicznego (max. poziom 3\%), bufora globalnych instytucji o znaczeniu systemowym (max. poziom 3,5\%) oraz częściowo bufora ryzyka systemowego (max. poziom $5 \%$ ). Przyczyną tego może być niski poziom ryzyka systemowego $\mathrm{w}$ polskim sektorze bankowym $\mathrm{w}$ porównaniu do europejskiego, który nie wskazał na konieczności wprowadzenia niektórych buforów kapitałowych, m.in. antycyklicznego oraz bufora globalnych instytucji o znaczeniu systemowym.

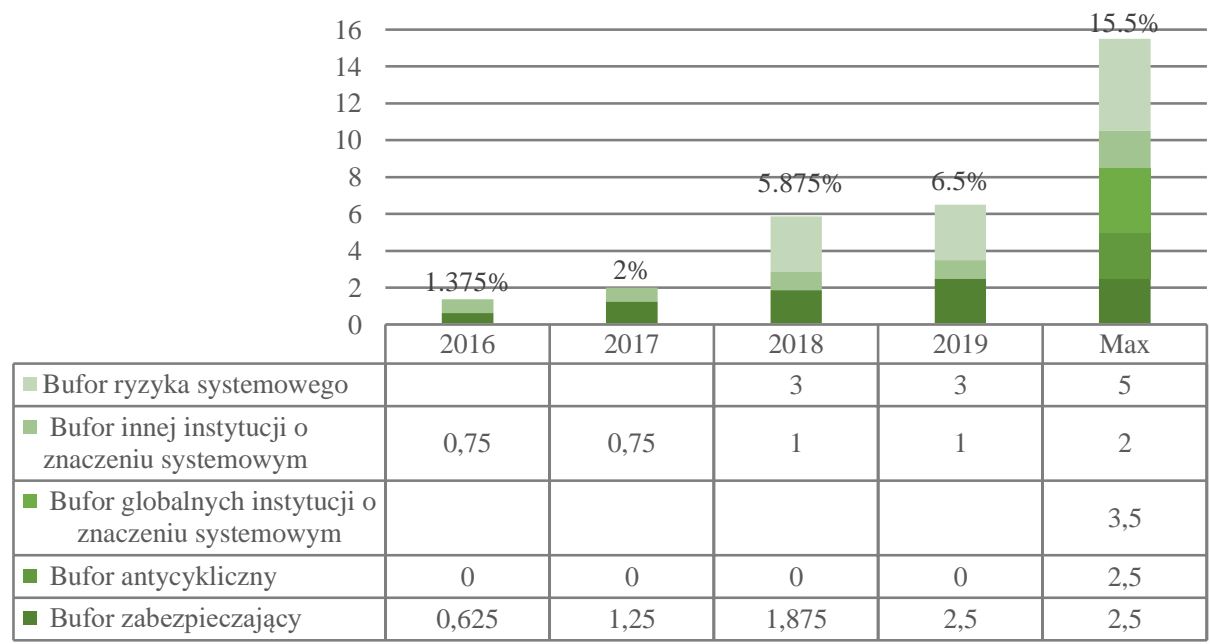

Wykres 1. Poziom wymogu połączonego bufora w polskim sektorze bankowym w latach 2016-2019,\%

Źródło: opracowanie własne na podstawie Komunikatów Komisji Nadzoru Finansowego w poszczególnych latach.

Przy tym należy podkreślić, iż w związku z pojawieniem się w 2020 roku zjawisk kryzysowych związanych z zagrożeniem epidemiologicznym COVID-19 w polskim sektorze bankowym zostały podjęte kroki mające na celu wsparcie aktywności banków. W szczególności, w dniu 16 marca 2020 roku Minister finansów po uwzględnieniu opinii KNF podpisał rozporządzenie dot. rozwiązania bufora ryzyka systemowego (3\%). Zniesienie bufora ryzyka systemowego, rekomendowane Komitetem Stabilności Finansowej, miało na celu ograniczyć negatywny wpływ koronawirusa na krajowy sektor bankowy i w efekcie na polską gospodarkę poprzez uwolnienie ok. $30 \mathrm{mld} \mathrm{zł} \mathrm{i} \mathrm{skierowanie} \mathrm{ich} \mathrm{na} \mathrm{podtrzymanie}$ akcji kredytowej. 


\section{EMPIRYCZNA WERYFIKACJA DOTRZYMANIA WYMOGU POŁAZCZONEGO BUFORA KAPITAŁOWEGO ORAZ ŁĄCZNEGO WSPÓŁCZYNNIKA KAPITAŁOWEGO W POLSKIM SEKTORZE BANKOWYM W LATACH 2016-2020}

Wymóg połączonego bufora jest uzupełnieniem wobec utrzymania minimalnych współczynników kapitałowych, które łącznie mają przyczynić się do zwiększenia odporności banku na straty katastroficzne oraz ograniczenie ryzyka niewypłacalności. Przy tym, istotną staje się analiza wielkości funduszy własnych przy ocenie bezpieczeństwa poszczególnych banków, jak i całego sektora bankowego, pod względem dotrzymania wymogu buforów kapitałowych oraz współczynników kapitałowych. W nawiązaniu do tego, poniżej zostanie przeprowadzona szczegółowa analiza poziomu współczynników kapitałowych polskiego sektora bankowego i ich porównanie z wymogem połączonego bufora oraz minimalnych poziomów współczynników kapitałowych, wyniki której zostały przedstawione w tabeli 3.

Tabela 3. Poziom wymogów połączonego bufora oraz współczynników kapitałowych polskiego sektora bankowego w latach 2016-2020 (w \%)

\begin{tabular}{|l|c|c|c|c|c|}
\hline \multicolumn{1}{|c|}{ Wyszczególnienie } & 2016 & 2017 & 2018 & 2019 & $2020^{*}$ \\
\hline Wymóg połączonego bufora, w tym: & 1,375 & 2 & 5,875 & 6,5 & 3,5 \\
\hline \multicolumn{1}{|c|}{ Bufor zabezpieczający } & 0,625 & 1,25 & 1,875 & 2,5 & 2,5 \\
\hline Bufor antycykliczny & - & 0 & 0 & 0 & 0 \\
\hline Bufor ryzyka systemowego & - & - & 3 & 3 & - \\
\hline $\begin{array}{l}\text { Bufor globalnych instytucji o znaczeniu syste- } \\
\text { mowym }\end{array}$ & - & - & - & - & - \\
\hline $\begin{array}{l}\text { Bufor innej instytucji o znaczeniu systemo- } \\
\text { wym }\end{array}$ & 0,75 & 0,75 & 1 & 1 & 1 \\
\hline Min. poziom współczynnika kapitału Tier 1 & 6 & 6 & 6 & 6 & 6 \\
\hline $\begin{array}{l}\text { Wymagany poziom współczynnika kapitału Tier 1 } \\
\text { z uwzględnieniem wymogu połączonego bufora }\end{array}$ & 7,375 & 8 & 11,875 & 12,5 & 9,5 \\
\hline Odnotowany poziom współczynnika kapitału Tier 1 & 16,14 & 17,21 & 17,13 & 17,03 & 18,4 \\
\hline Nadwyżka kapitału Tier 1 & 8,765 & 9,21 & 5,255 & 4,53 & 8,9 \\
\hline $\begin{array}{l}\text { Min. poziom łącznego współczynnika } \\
\text { kapitałowego }\end{array}$ & 8 & 8 & 8 & 8 & 8 \\
\hline $\begin{array}{l}\text { Wymagany poziom łącznego współczynnika } \\
\text { kapitałowego z uwzględnieniem wymogu } \\
\text { połączonego bufora }\end{array}$ & 9,375 & 10 & 13,875 & 14,5 & 11,5 \\
\hline $\begin{array}{l}\text { Odnotowany poziom łącznego współczynnika } \\
\text { kapitałowego }\end{array}$ & 17,72 & 18,96 & 19,05 & 19,08 & 20,42 \\
\hline $\begin{array}{l}\text { Nadwyżka funduszy własnych (łącznego } \\
\text { współczynnika kapitałowego) }\end{array}$ & 8,345 & 8,96 & 5,175 & 4,58 & 8,92 \\
\hline
\end{tabular}

* na dzień 30 września 2020 roku.

Źródło: opracowanie własne na podstawie danych KNF, Dane miesięczne sektora bankowego - grudzień 2020. 
Wynika z niej, iż w latach 2016-2020 w polskim sektorze bankowym można odnotować nadwyżkę funduszy własnych. To oznacza, iż wymóg połączonego bufora oraz minimalnych współczynników kapitałowych był wykonany. Świadczyć to może o tym, iż polski sektor bankowy posiada mocną pozycję kapitałową i jest bezpieczny pod względem wykonania wymogu połączonego bufora. Nadwyżka funduszy własnych $\mathrm{w}$ analizowanym okresie kształtowała się $\mathrm{w}$ przedziale 4-9\% i wynikała głównie z zatrzymania w bankach zysków wypracowanych w poprzednich latach.

Ponadto należy odnotować spadającą tendencję wielkości nadwyżki funduszy własnych nad poziomem wymaganym, w szczególności w latach 2018-2019. To mogło być związane z wprowadzeniem obowiązku utrzymania bufora ryzyka systemowego w wysokości 3\% od 2018 roku. Z komunikatów KNF wynika, iż w kolejnych latach wysokość wymogu połączonego bufora może nadal zwiększać się. Zwiększające się wymogi co do wielkości i jakości kapitału mogą oznaczać ograniczone możliwości wypłaty dywidendy przez banki, lecz z pewnością przyczyni się to do wzmocnienia polskiego sektora bankowego i uodpornienia go na ewentualne zaburzenia o charakterze systemowym. Podsumowując, należy podkreślić, iż w latach 2016-2020 polski sektor bankowy jako całość spełnia minimalne wymogi kapitałowe, w tym wymóg połączonego bufora, określone w pakiecie regulacyjnym CRD IV/CRR.

Analizując sytuację w polskim sektorze bankowym w 2020 roku pod względem dotrzymania wymogu połączonego bufora, należy podkreślić, iż w związku z pojawieniem się zjawisk kryzysowych związanych z zagrożeniem epidemiologicznym COVID-19 w polskiej gospodarce zostały podjęte kroki mające na celu wsparcie aktywności podmiotów gospodarczych. W sektorze bankowym przejawiło działania te przejawiły się poprzez poluzowanie niektórych wymagań regulacyjnych oraz odłożenie w czasie wejścia w życia niektórych nowych obowiązków regulacyjnych, m.in. obowiązek wdrożenia rekomendacji R został odłożony w czasie przez KNF ze względu na epidemię COVID-19 (pierwotnie Rekomendacja R (Stanowisko Urzędu Komisji Nadzoru Finansowego w ramach Pakietu Impulsów Nadzorczych 2020) miała wejść w życie do końca 2020 roku) oraz przesunięcie terminu wdrożenia Rekomendacji S do dnia 30.06.2021 (Komunikat KNF z dnia 14 lipca 2020 r.).

W szczególności, w dniu 16 marca 2020 roku Minister finansów po uwzględnieniu opinii KNF podpisał rozporządzenie dot. rozwiązania bufora ryzyka systemowego $(3 \%)^{5}$. Dodatkowo, Komisja Nadzoru Finansowego, zgodnie

\footnotetext{
${ }^{5}$ Komitet Stabilności Finansowej działając w formule makroostrożnościowej, któremu przewodniczy Prezes NBP, zarekomendował zniesienie bufora ryzyka systemowego, który wynosił 3\%. Realizując tę rekomendację, Minister Finansów wydał w dniu 18 marca 2020 r. rozporządzenie zwalniające banki z obowiązku utrzymywania bufora ryzyka systemowego. W efekcie tej decyzji w bankach uwolniony został zasób ok. 30 mld zł kapitału. W ocenie Komitetu umożliwienie bankom
} 
z zaleceniami EBA oraz EBC, zaleciła bankom nie wypłacać dywidend i zatrzymać cały wypracowany zysk z lat poprzednich (Wypowiedź Przewodniczącego KNF...).

Przy tym należy podkreślić, iż polski sektor bankowy wszedł w okres pandemii COVID-19 w dobrej kondycji, odporny na szoki i bez znaczących nierównowag. W odróżnieniu od globalnego kryzysu finansowego z 2008 r., przed którym akcja kredytowa rosła bardzo dynamicznie, w ostatnich latach nie występowały napięcia na rynku kredytowym. Jednocześnie znacząco podniesiono odporność sektora bankowego, zarówno poprzez zwiększenie kapitałów, jak również poprzez podniesienie jakości zarządzania ryzykiem. Jak zaznacza się w raporcie raporcie NBP Wydanie specjalne: skutki pandemii COVID-19, sektor bankowy w pierwszej połowie 2020 roku charakteryzował się stabilnym finansowaniem i wysoką płynnością (Raport o stabilności systemu Finansowego, 2020: 7).

\section{PODSUMOWANIE}

Podsumowując należy podkreślić, iż bufory kapitałowe mają na celu zwiększenie odporności banku oraz całego sektora bankowego na straty katastroficzne i ograniczenie ryzyka niewypłacalności. Ponadto bufory kapitałowe, w szczególności zabezpieczający i antycykliczny, zalicza się do narzędzi polityki makroostrożnościowej, które umożliwiają przeciwdziałanie ryzyku systemowemu oraz usunięciu procykliczności w działalności bankowej. Bufory kapitałowe są nadwyżką kapitału podstawowego Tier 1 (CET1) w stosunku do kapitałów wypełniających normę współczynnika wypłacalności. Z jednej strony, ta nadwyżka kapitału powoduje obniżenie stopy zwrotu z kapitału, ale z drugiej strony - również prowadzi do obniżenia ryzyka bankructwa.

Wyniki badania empirycznego wskazują, iż w latach 2016-2020 w polskim sektorze bankowym została odnotowana nadwyżka funduszy własnych. To oznacza spełnienie przez ten sektor bankowy jako całości minimalnych wymogów kapitałowych, w tym wymogu połączonego bufora, określonych w pakiecie regulacyjnym CRD IV/CRR. To potwierdza, iż bufory kapitałowe zwiększają poziom bezpieczeństwa polskiego sektora bankowego.

wykorzystania środków z bufora zmniejsza ryzyko ograniczenia dopływu kredytu do gospodarki. (Rozporządzenie Ministra Finansów z dnia 18 marca 2020 r.; Raport o stabilności systemu Finansowego, 2020: 31). 


\section{BIBLIOGRAFIA}

Capital requirements for the banking sector, Rada Europejska Rada Unii Europejskiej, https://www.consilium.europa.eu/pl/policies/banking-union/single-rulebook/capital-requirements/ [dostęp: 24.11.2020].

Dobrzańska, A., Kurowski, Ł. (2019). Antycykliczny bufor kapitałowy jako instrument polityki makroekonomicznej. Dotychczasowe doświadczenia w Unii Europejskiej. Bezpieczny Bank, 1(74).

Dyrektywa CRD IV Parlamentu Europejskiego i Rady 2013/36/UE z dnia 26 czerwca 2013 r. w sprawie warunków dopuszczenia instytucji kredytowych do działalności oraz nadzoru ostrożnościowego nad instytucjami kredytowymi i firmami inwestycyjnymi, zmieniająca dyrektywę 2002/87/WE i uchylająca dyrektywy 2006/48/WE oraz 2006/49/WE, https://eurlex.europa.eu/legal-content/PL/TXT/PDF/?uri=CELEX:32013L0036\&from=DE [dostęp: 03.03.2021].

Komisja Nadzoru Finansowego [KNF], Dane miesięczne sektora bankowego - grudzień 2020, https://www.knf.gov.pl/?articleId=56224\&p_id=18 [dostęp: 1.02.2021].

Komunikat KNF z dnia 14 listopada 2016 r. w sprawie identyfikacji innych instytucji o znaczeniu systemowym, https://www.knf.gov.pl/knf/pl/komponenty/img/instytucje_o_znaczeniu_systemowym_OSII_14_11_2016_54988.pdf [dostęp: 12.02.2021].

Komunikat KNF z dnia 15 lipca 2020 r. w sprawie decyzji podjętych przez Komisję Nadzoru Finansowego w dniu 14 lipca 2020 r., https://www.knf.gov.pl/knf/pl/komponenty/img/Komunikat_ws_decyzji_KNF_14_07_2020_70277.pdf [dostęp: 12.02.2021].

Komunikat KNF z dnia 15 października 2019 r. w sprawie Przeglądu adekwatności wskaźnika bufora innej instytucji o znaczeniu systemowym, https://www.knf.gov.pl/knf/pl/komponenty/img/Komunikat_KNF_ws_buforow_innej_instytucji_o_znaczeniu_systemowym_67416.pdf [dostęp: 13.02.2021].

Komunikat KNF z dnia 8 sierpnia 2018 r. w sprawie Przeglądu adekwatności wskaźnika bufora innej instytucji o znaczeniu systemowym, https://www.knf.gov.pl/knf/pl/komponenty/img/Komunikat_OSII_PL_8_08_2018_62553.pdf [dostęp: 13.02.2021].

Komunikat KNF z dnia 9 listopada 2020 r. w sprawie Przeglądu adekwatności wskaźnika bufora innej instytucji o znaczeniu systemowym, https://www.knf.gov.pl/knf/pl/komponenty/img/Przeglad_adekwatnosci_wskaznika_bufora_innej_instytucji_o_znaczeniu_systemowym_71357.pdf [dostęp: 13.02.2021].

Komunikat KNF z dnia 9 stycznia 2018 r. w sprawie Przeglądu adekwatności wskaźnika bufora innej instytucji o znaczeniu systemowym, https://www.knf.gov.pl/knf/pl/komponenty/img/Komunikat_OSII_2017.pdf [dostęp: 13.02.2021].

Komunikaty KNF, https://www.knf.gov.pl/komunikacja/komunikaty [dostęp: 12.02.2021].

Marcinkowska, M. (2012). Charakterystyka regulacji kapitałowych. W: M. Marcinkowska, P. Wdowiński, red., Wpływ regulacji kapitałowych i płynnościowych sektora bankowego na wzrost gospodarczy Polski. Łódź: Wydawnictwo Uniwersytetu Łódzkiego.

Miklaszewska, E., Kil K. (2019). Skuteczność rozwiązań i mechanizmów stabilizujących banki systemowo ważne w krajach Unii Europejskiej w okresie pokryzysowym - próba oceny. Bank i Kredyt, 50(2).

Moser, K. (2018). Rozwój nadzoru makroostrożnościowego, Metody zapobiegania kryzysom finansowym. Państwo i Społeczeństwo, 1. 
Pawłowicz, L. (2011). Optymalizacja alokacji kapitału w budowaniu wartości banku dla akcjonariuszy. Kwartalnik Nauk o Przedsiębiorstwie, 2011/1.

Raport o stabilności systemu Finansowego, Wydanie specjalne: skutki pandemii COVID-19, 2020, Narodowy Bank Polski, https://www.nbp.pl/systemfinansowy/rsf062020.pdf [dostęp: 15.03.2021].

Rozporządzenie Ministra Finansów z dnia 18 marca 2020 r. uchylające rozporządzenie w sprawie bufora ryzyka systemowego, Dz.U. 2020, poz. 473, http://isap.sejm.gov.pl/isap.nsf/DocDetails.xsp?id=WDU20200000473 [dostęp: 15.04.2021].

Rozporządzenie Ministra Rozwoju i Finansów z 1 września 2017 r. w sprawie ryzyka systemowego, Dz.U. 2017, poz. 1776.

Stanowisko Urzędu Komisji Nadzoru Finansowego w ramach Pakietu Impulsów Nadzorczych ws. finansowania przez banki klientów korporacyjnych w obliczu pandemii koronawirusa, 31 marca 2020 r., https://www.knf.gov.pl/knf/pl/komponenty/img/Stanowisko_UKNF_ws_finansowania_przez_banki_klientow_korporacyjnych_69405.pdf [dostęp: 30.04.2021].

Ustawa $\mathrm{z}$ dnia 5 sierpnia $2015 \mathrm{r}$. o nadzorze makroostrożnościowym nad systemem finansowym i zarządzaniu kryzysowym w systemie finansowym, Dz.U. 2015, poz. 1513.

Wypowiedź Przewodniczącego KNF ws. dywidend banków oraz zakładów ubezpieczeń, https://www.knf.gov.pl/knf/pl/komponenty/img/Wypowiedz_Przewodniczacego_KNF_ws_dywidend_bankow_oraz_zakladow_ubezpieczen.pdf [dostęp: 30.04.2021].

\section{BUFORY KAPITAŁOWE JAKO DETERMINANTY BEZPIECZEŃSTWA SEKTORA BANKOWEGO: ANALIZA EMPIRYCZNA SPEŁNIENIA WYMOGU POŁĄCZONEGO BUFORA}

\section{Streszczenie}

Cel artykułu. Celem artykułu jest ocena znaczenia buforów kapitałowych w zapewnieniu bezpieczeństwa poszczególnych banków oraz całego sektora bankowego. W niniejszym opracowaniu naukowym scharakteryzowano wysokość wymogu bufora zabezpieczającego, bufora antycyklicznego, bufora ryzyka systemowego, bufora innych instytucji o znaczeniu systemowym w polskim sektorze bankowym. Ponadto została przeprowadzona analiza empiryczna wymogu kapitałowego uwzględniającego wymóg połączonego bufora oraz łącznego współczynnika kapitałowego w polskim sektorze bankowym.

Metodyka. W obliczeniach wykorzystano dane finansowe udostępnione przez Komisję Nadzoru Finansowego oraz skonsolidowane sprawozdania finansowe banków w Polsce. Aby osiągnąć postawiony cel posłużono się metodą porównywania dokumentów i aktów prawnych (szczególnie w części dotyczącej charakterystyki buforów kapitałowych) oraz metodami statystyki opisowej (w empirycznej części podrozdziału).

Wyniki badania. Powyższa analiza jest podstawą do odpowiedzi na pytanie, czy pokryzysowe bufory kapitałowe zwiększają poziom bezpieczeństwa polskiego sektora bankowego.

Słowa kluczowe: bank, sektor bankowy, fundusze własne, bufory kapitałowe, bezpieczeństwo. 